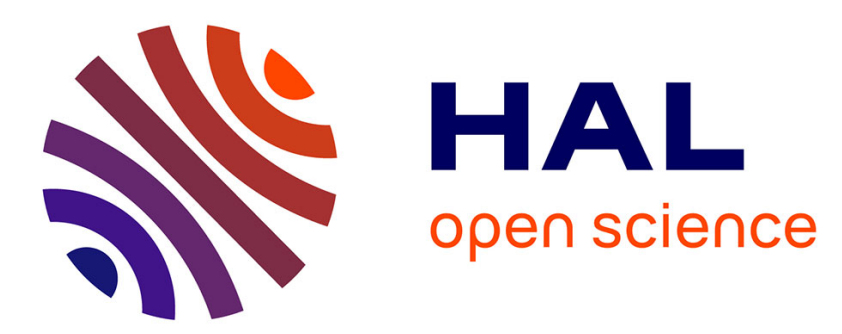

\title{
Can Supported Reduced Vanadium Oxides form H2 from CH3OH? A Computational Gas-Phase Mechanistic Study
}

Patricio González-Navarrete, Juan Andres, Monica Calatayud

\section{- To cite this version:}

Patricio González-Navarrete, Juan Andres, Monica Calatayud. Can Supported Reduced Vanadium Oxides form H2 from CH3OH? A Computational Gas-Phase Mechanistic Study. Journal of Physical Chemistry A, 2018, 122 (4), pp.1104-1113. 10.1021/acs.jpca.7b11264 . hal-02496871

\section{HAL Id: hal-02496871 https://hal.science/hal-02496871}

Submitted on 3 Mar 2020

HAL is a multi-disciplinary open access archive for the deposit and dissemination of scientific research documents, whether they are published or not. The documents may come from teaching and research institutions in France or abroad, or from public or private research centers.
L'archive ouverte pluridisciplinaire HAL, est destinée au dépôt et à la diffusion de documents scientifiques de niveau recherche, publiés ou non, émanant des établissements d'enseignement et de recherche français ou étrangers, des laboratoires publics ou privés. 
Can Supported Reduced Vanadium Oxides form $\mathrm{H}_{2}$ from $\mathrm{CH}_{3} \mathrm{OH}$ ? A

Computational Gas-Phase Mechanistic Study

\title{
Patricio González-Navarrete, ${ }^{\star 1}$ Juan Andrés ${ }^{1}$ and Monica Calatayud ${ }^{\star 2,3}$
}

1Departament de Química Física i Analítica, Universitat Jaume I, Av. Sos Baynat S/N, 12071 Castelló, Spain

${ }^{2}$ Sorbonne Universités, UPMC Univ Paris 06, CNRS, Laboratoire de Chimie Théorique CC 137, 4, place Jussieu F. 75252, Paris Cedex 05, France ${ }^{3}$ Institut Universitaire de France, France

*Corresponding authors: calatayu@Ict.jussieu.fr; pgonzale@uji.es

\begin{abstract}
A detailed density functional theory study is presented to clarify the mechanistic aspects of the methanol, $\mathrm{CH}_{3} \mathrm{OH}$, dehydrogenation process to yield hydrogen, $\mathrm{H}_{2}$, and formaldehyde, $\mathrm{CH}_{2} \mathrm{O}$. A gas-phase vanadium oxide cluster is used as a model system to represent reduced $\mathrm{V}$ (III) oxides supported on $\mathrm{TiO}_{2}$ catalyst. The theoretical results provide a complete scenario, involving several reaction pathways in which different methanol adsorption sites are considered, with presence of hydride and methoxide intermediates. Methanol dissociative adsorption process is both kinetically and thermodynamically feasible on $\mathrm{V}-\mathrm{O}-\mathrm{Ti}$ and $V=O$ sites, and it might lead to form hydride species with interesting catalytic reactivity. The formation of $\mathrm{H}_{2}$ and $\mathrm{CH}_{2} \mathrm{O}$ on reduced vanadium sites, $\mathrm{V}(\mathrm{III})$, is found to be more favorable than for oxidized vanadium species $\mathrm{V}(\mathrm{V})$, taking place along energy barriers of $29.9 \mathrm{kcal} / \mathrm{mol}$ and $41.0 \mathrm{kcal} / \mathrm{mol}$ respectively.
\end{abstract}


TOC

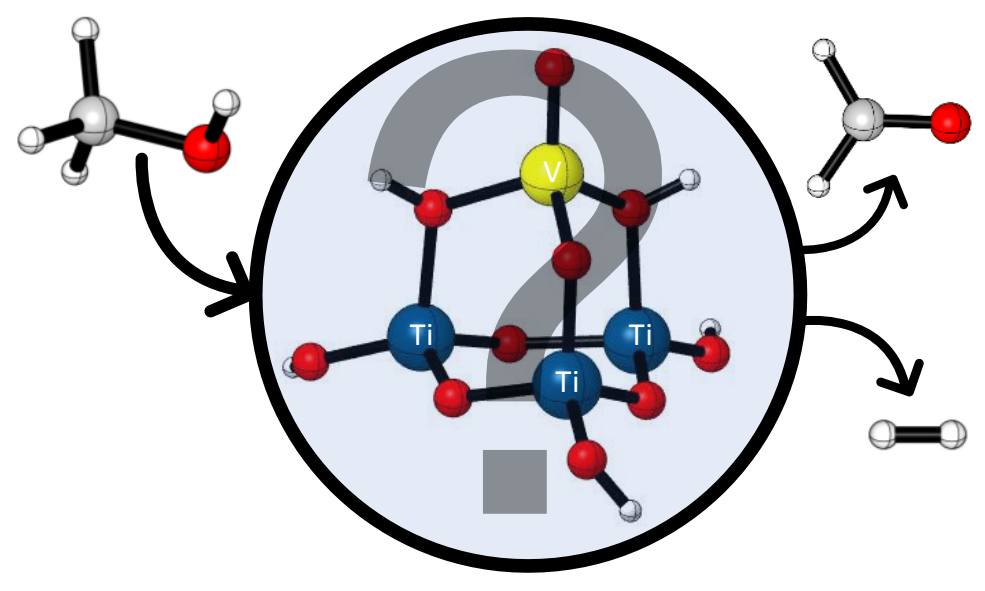




\section{Introduction}

The dehydrogenation of methanol, $\mathrm{CH}_{3} \mathrm{OH}$, is of considerable interest from an academic and an industrial viewpoint due to its importance in many practical applications. $\mathrm{CH}_{3} \mathrm{OH}$ is widely used as a fuel, solvent, and raw material for producing chemicals and other materials; in particular, the chemical transformation of $\mathrm{CH}_{3} \mathrm{OH}$ to hydrogen, $\mathrm{H}_{2}$, allows considering methanol as a renewable alternative to petroleum-based hydrocarbons, thus opening the door for a possible future "methanol economy". ${ }^{1-4}$

On the other hand, $\mathrm{CH}_{3} \mathrm{OH}$ has been widely studied and utilized as a smart chemical probe molecule in order to establish the fundamental structureactivity relationships for metal oxide catalysts..$^{5-9}$ Despite its vast use, there is still a lack of understanding on the nature of the reaction mechanisms involved in the catalytic transformations, due mainly to the difficulty for obtaining representative model systems on which to carry out detailed chemical and kinetic analyses. In this context, extensive research efforts have been made both experimentally and theoretically to search for suitable catalysts to improve chemical processes concerning alcohol transformations; ${ }^{10}{ }^{11}$ Likewise, gasphase experiments combined with theoretical works ${ }^{12-18}$ have provided a wealth of information of elementary steps and intermediates for various catalytic reactions, ${ }^{19-37}$ and provides ideal model systems for local reactive sites of condensed-phase catalysts. Therefore, small transition metal oxides clusters may well be effective models of real surface species or active sites over the bulk transition metal oxides materials, ${ }^{38}$ that are capable to provide a conceptual framework for modifying or controlling the chemical properties of mixed-metal oxides and for engineering industrial catalysts.

Metal oxide catalysts are more complex than conventional metal catalysts because they can terminate with multiple surface functionalities and expose cations in multiple oxidation states. ${ }^{39-43}$ In particular, vanadium oxide is an example of such complex behaviour, and several experimental and theoretical investigations have previously been carried out to quantify the number of surface active sites, understanding their structure/reactivity correlations, ${ }^{44-47}$ and also the kinetic aspects of methanol oxidation to 
formaldehyde. ${ }^{34,48-79}$ What all those catalytic studies have in common is a supported vanadium $(\mathrm{V})$ species in which an oxidative dehydrogenation process occurs, i.e. an electron transfer from the methanol toward the catalyst takes place with concomitant reduction of $\mathrm{V}(\mathrm{V})$ to $\mathrm{V}(\mathrm{III})$. However, the influence of formal oxidation state and the reactivity of isolated functional groups that form the active sites are still unexplored on supported vanadium catalysts. In this sense, gas-phase cluster studies have been previously carried out both theoretically and experimentally concerning the role of the oxidation state in vanadium oxides towards methanol. ${ }^{25,80}$ In particular, Schwarz et al. have demostrated that the reaction of $\mathrm{VO}^{+}$with $\mathrm{CH}_{3} \mathrm{O}$ yields $\mathrm{CH}_{2} \mathrm{O}$ and $\mathrm{H}_{2}$ along a 1,2-elimination process to produce $\mathrm{CH}_{2} \mathrm{O}$ and $\mathrm{H}_{2}{ }^{25,80}$

In the present study, we seek to fulfil a three-fold objective. First, to propose several reaction pathways to unravel the mechanistic aspects for the dehydrogenation process of $\mathrm{CH}_{3} \mathrm{OH}$ to render the formation of $\mathrm{H}_{2}$ and $\mathrm{CH}_{2} \mathrm{O}$ on reduced vanadium oxides supported on $\mathrm{TiO}_{2}$ catalyst. Different $\mathrm{CH}_{3} \mathrm{OH}$ adsorption sites as well as the presence of hydride and methoxide intermediates along the reaction coordinate has been considered. Secondly, to unravel the role of the formal oxidation state of the vanadium center, $\mathrm{V}(\mathrm{V})$ vs $\mathrm{V}(\mathrm{III})$, in the reaction mechanisms by analyzing the electronic structure of the process along the reaction coordinate. Thirdly, to compare the results with those previously obtained by some of us for models containing oxidized $\mathrm{V}(\mathrm{V})$ species $^{29,70,79}$, which highlight the role of electronic and geometric factors on chemical reactivity.

The remainder of the paper is organized as follows; computational details and model systems are presented in section 2. The analysis and discussion of the results are presented in section 3. The main conclusions are given in section 4.

\section{Computational details and model systems}

All the quantum chemical calculations were performed using the Gaussian 09 code. ${ }^{81}$ Stationary points on the potential energy surfaces (PESs) have been characterized using density functional theory (DFT) at the hybrid B3LYP ${ }^{82-84}$ functional level together with the $6-311 \mathrm{G}(2 \mathrm{~d}, \mathrm{p})^{85}$ basis set in all 
atoms. Previous theoretical studies on isolated vanadates supported on titania $^{72,77}$ have been carried out by using the pseudo-potential on metal atoms; however, it is well-known that all-electron basis set renders more accurate results regarding energetic and geometry than the use of pseudo-potentials. ${ }^{68}$, 86, 87 We have already applied this level of theory to calculate molecular mechanisms on selective methanol oxidation to formaldehyde on hydrated and supported isolated vanadates, ${ }^{70,79}$ and then, we are confident with the data calculated at this computing level for this type of reaction.

The local minima of the stationary structures were located and characterized performing analysis of the calculated vibrational frequencies. Thermodynamic properties were obtained for all species involved in the reaction mechanisms. The Gibbs free energy was computed using the standard equations of statistical mechanics ${ }^{88,89}$ at $373 \mathrm{~K}$.

Based on a similar model to that used to represent isolated vanadate species supported on titania, ${ }^{29}$ our catalytic representation corresponds to a $\mathrm{TiO}_{2}$-supported vanadium oxide, in which vanadium oxide contains a terminal vanadyl bond $(\mathrm{V}=\mathrm{O})$, and three bridging oxygen atoms ( $\mathrm{V}-\mathrm{O}-\mathrm{Ti}$ sites). Two hydrogen atoms are added to the model ( $\mathrm{V}-\mathrm{OH}-\mathrm{Ti}$ sites), see figure 1. The addition of the two neutral hydrogen atoms results both in a reduction of $\mathrm{V}(\mathrm{V})$ to $\mathrm{V}$ (III) and the formation of the V-OH-Ti hydroxyl sites. These two species are expected on the catalyst surface after methanol oxidation to formaldehyde: reduced vanadia is reported /algunas citas experimentales/ and hydroxylated vanadia species can be stabilized even at high temperature depending on the hydration and vanadia content / J.Phys.Chem.C 2011, 115, 24133-24142, J. Phys. Chem. C, 2013, 117 (48), pp 25535-25544 DOI: 10.1021/jp408836d /. Moreover, upon hydrogenation of $\mathrm{V}_{2} \mathrm{O}_{5}-\mathrm{TiO}_{2}$ model catalysts the $\mathrm{V}$-O-Ti sites are found to be more reactive than $\mathrm{V}=\mathrm{O}$ or $\mathrm{V}-\mathrm{O}-\mathrm{V}$ sites // Topics in Catalysis Vol. 40, Nos. 1-4, December 2006 (_ 2006) 17 DOI: 10.1007/s11244-006-0090x // J. Phys. Chem. B 2004, 108, 15679-15685// J. Phys. Chem. C 2007, 111, 6411-6417/, forming $\mathrm{V}-\mathrm{OH}-\mathrm{Ti}$ species and reducing $\mathrm{V}^{5+}$ to $\mathrm{V}^{4+} / \mathrm{V}^{3+}$.

In this model (S1) the vanadium site possesses an oxidation state of $\mathrm{V}$ (III) in a tetrahedral environment, and a triplet electronic ground state. Although alternative models have been proposed on supported isolated vanadate species ${ }^{67,76}$ the pyramid arrangement seems to be the most generally 
assumed, and therefore, we have considered it to carry out our calculations. Three different interactions between methanol and the cluster are considered, involving the interface $\mathrm{V}-\mathrm{O}-\mathrm{Ti}$, the vanadyl $\mathrm{V}=\mathrm{O}$ and the $\mathrm{V}$ site, as displayed in figure 2 .

\section{Result and discussion}

\subsection{Adsorption and dissociation of $\mathrm{CH}_{3} \mathrm{OH}$}

It is well-known that the interaction of one $\mathrm{CH}_{3} \mathrm{OH}$ molecule with the catalyst surface is favorable $e^{61,63}$ and it can be associated with weak electrostatic interactions between the vanadium site (acidic) and the oxygen atom of methanol molecule (basic). ${ }^{29}$ In our gas-phase cluster model the interaction of $\mathrm{CH}_{3} \mathrm{OH}$ with surface results in the formation of two encounter complexes (MO and M3) with geometric parameters similar to those of separated reactants. In the M0 intermediate, this interaction takes place mainly between the hydroxyl group of methanol and V-O-Ti site, whereas in M3 it appears at the $\mathrm{V}=\mathrm{O}$ bond, see figures 3 and 4 . The formation of these adducts are exothermic processes by 19.0 and $16.3 \mathrm{kcal} / \mathrm{mol}$, respectively. For the activation of $\mathrm{CH}_{3} \mathrm{OH}$, it is necessary a proton transfer process from hydroxyl group of $\mathrm{CH}_{3} \mathrm{OH}$ towards either $\mathrm{V}$-O-Ti or $\mathrm{V}=\mathrm{O}$, with a total (and free) energy barriers of 6.9 (7.6) and $13.2(15.1) \mathrm{kcal} / \mathrm{mol}$, via the transition states $\mathrm{TS}_{0-1}$ and $\mathrm{TS}_{3-4}$, respectively, to yield the formation of methoxide $\mathrm{V}-\mathrm{OCH}_{3}$ species, represented by $\mathrm{M} 1$ and $\mathrm{M} 4$, with exothermic adsorption energies of -15.2 and $-32.5 \mathrm{kcal} / \mathrm{mol}$, respectively, see figure 2. The effect of temperature at $373 \mathrm{~K}$ shows a quasi-equilibrated process of molecular-methanol adsorption, i.e. $M 0$ and $M 3$, with $\Delta G$ values of 4.6 and $-3.1 \mathrm{kcal} / \mathrm{mol}$, respectively. Therefore, the effect of the temperature results in a quasi-indistinguishable molecular adsorption site. Likewise, methanol adsorption on $\mathrm{V}-\mathrm{O}-\mathrm{Ti}$ sites can be assumed as a quasi-equilibrated process with $\Delta G=-1.2 \mathrm{kcal} / \mathrm{mol}$, whereas the adsorption on $V=O$ sites is predicted significantly more exergonic $(\Delta G=-19.7 \mathrm{kcal} / \mathrm{mol})$. Alternatively, methanol adsorption concerning the formation of hydride-methoxy-intermediate (M7) has been also considered, see figures 2 and 6. A proton transfer from hydroxyl group of methanol toward vanadium site results in the formation of M7. This process is predicted to be exothermic by $20.4 \mathrm{kcal} / \mathrm{mol}$ and $\Delta G=-6.7$ 
$\mathrm{kcal} / \mathrm{mol}$, see figure 2 , although this route via a hydride intermediate is kinetically less favorable than those predicted for $\mathrm{V}-\mathrm{O}-\mathrm{Ti}$ and $\mathrm{V}=\mathrm{O}$ sites. The formation of M7 involves a change in the formal oxidation state of vanadium atom, $\mathrm{V}(\mathrm{III}) \rightarrow \mathrm{V}(\mathrm{V})$, as well as a spin crossing process, being a typical two state reactivity (TSR) scenario. ${ }^{90}$ The importance of hydride intermediates in the $\mathrm{H}_{2}$ production from $\mathrm{CH}_{3} \mathrm{OH}$ on transition metal atoms has been remarked by Zhou et al. ${ }^{91}$, while Schwarz et al. have reported the presence of hydride intermediates in the dehydrogenation of $\mathrm{CH}_{3} \mathrm{OH}$ with mononuclear vanadiumoxide cations ${ }^{80}$ with presence of $\mathrm{V}$ (III) oxidation state. We conclude thus that hydride intermediates might have an important role when vanadium is (partially) reduced i.e. when its formal oxidation state is lower than $\mathrm{V}(\mathrm{V})$.

To sum up, the dissociation of $\mathrm{CH}_{3} \mathrm{OH}$ both by $\mathrm{V}=\mathrm{O}$ bond and $\mathrm{V}-\mathrm{O}-\mathrm{Ti}$ sites is clearly favorable in V(III) models, whereas hydride-intermediates may not be taken into account as a feasible reaction channel since its formation is achieved along a higher energetic demand. In contrast, the formation of M7 intermediate can be not favorable according the description of the model system. However, titania-supported vanadium oxide surface undergoes dynamic changes under reaction conditions, which can involve the changes in the oxidation state between $\mathrm{V}(\mathrm{V})$ and $\mathrm{V}(\mathrm{III})$. Additional factors such as water and the effect of support can play a role in the stabilization of the vanadium oxidation state.

\subsection{Exploration of reaction pathways}

To understand the dehydrogenation process of $\mathrm{CH}_{3} \mathrm{OH}$ on reduced vanadium oxide cluster supported on titania, we have explored three reaction pathways: Path A, Path B1 and Path B2, starting from the methanol and the catalyst model ( $\mathrm{S} 1)$ as reference.

In the first step along the path $\mathrm{A}$, the $\mathrm{CH}_{3} \mathrm{OH}$ adsorption process occurs at the V-O-Ti site to render the methoxy-intermediate M1. In the next stage, via $\mathrm{TS}_{1-2}$, the $\mathrm{H}_{2}$ and product-complex $\mathrm{M} 2$ are formed by recombination of the $\mathrm{CH}_{3}$ of $\mathrm{CH}_{3} \mathrm{OH}$ and $\mathrm{OH}$ group of the support; thus, two electrons are transferred from the $\mathrm{CH}_{3} \mathrm{OH}$ molecule to form $\mathrm{H}_{2}$ avoiding thus a change in the formal oxidation state of the vanadium center, while the system remains in its triplet ground state. 
The formation of $\mathrm{H}_{2}$ is predicted to have an activation energy barrier of $36.4 \mathrm{kcal} / \mathrm{mol}\left(\Delta G^{\dagger}=38.2 \mathrm{kcal} / \mathrm{mol}\right)$, while $\mathrm{M} 2$ is calculated to be $19.2 \mathrm{kcal} / \mathrm{mol}$ higher in energy than $\mathrm{M} 1$. In $\mathrm{M} 2, \mathrm{H}_{2}$ interacts with the oxygen atom of $\mathrm{V}=\mathrm{O}$ site whereas the interaction of $\mathrm{CH}_{2} \mathrm{O}$ is mainly between the oxygen of carbonyl bond and the vanadium atom. The intermediate M2 presents two $\mathrm{V}-(\mathrm{OH})-\mathrm{Ti}$ groups as well as a vanadyl $\mathrm{V}=\mathrm{O}$ group. Finally, $\mathrm{CH}_{2} \mathrm{O}$ and $\mathrm{H}_{2}$ desorb with values of $\Delta E=$ $13.0 \mathrm{kcal} / \mathrm{mol}$ (and $\Delta G=-7.1 \mathrm{kcal} / \mathrm{mol}$ ).

Path $\mathrm{B} 1$ contemplates firstly the methanol dissociation by vanadyl bond to form M4. Later, the formation of $\mathrm{H}_{2}$ and $\mathrm{CH}_{2} \mathrm{O}$ is reached by means of $\mathrm{H}$ transfer process from the adsorbed methoxy group toward the hydrogen atom of the recently formed $\mathrm{OH}$ group, via $\mathrm{TS}_{4-2}$. This step is associated with an activation energy barrier of $53.5\left(\Delta G^{\dagger}=55.4\right) \mathrm{kcal} / \mathrm{mol}$. The vanadyl bond is recovered in this step, leading to the product-complex $\mathrm{M} 2$, which is also found in Path A. M2 is $36.5 \mathrm{kcal} / \mathrm{mol}$ (and $\Delta G=35.0 \mathrm{kcal} / \mathrm{mol}$ ) less stable than the preceding intermediate $\mathrm{M} 4$.

On Path $\mathrm{B} 2, \mathrm{CH}_{3} \mathrm{OH}$ dissociation process takes place identically as it occurs along the Path $\mathrm{B} 1$. Then, the formation of $\mathrm{H}_{2}$ and $\mathrm{CH}_{2} \mathrm{O}$ is achieved by means of hydride transfer from the $\mathrm{CH}_{3}$ group toward one of the $\mathrm{OH}$ group from the support via $\mathrm{TS}_{4-5}$ (see figure 5). This step has an activation energy barrier of $29.0 \mathrm{kcal} / \mathrm{mol}\left(\Delta G^{\dagger}=32.0 \mathrm{kcal} / \mathrm{mol}\right)$. The product-complex M5 is predicted only $4 \mathrm{kcal} / \mathrm{mol}(\Delta G=3.8)$ less stable than M4. Finally, $\mathrm{CH}_{2} \mathrm{O}$ and $\mathrm{H}_{2}$ desorb with $\Delta E$ $=20.2 \mathrm{kcal} / \mathrm{mol}(\Delta G=-0.5 \mathrm{kcal} / \mathrm{mol})$ leaving the catalyst as in S2, see Figure 1 . Note that the final product $\mathrm{S} 2+\mathrm{CH}_{2} \mathrm{O}+\mathrm{H}_{2}$ is predicted to be $8.3 \mathrm{kcal} / \mathrm{mol}$ more stable than $\mathrm{S} 1+\mathrm{MeOH}$, being the conversion of $\mathrm{S} 1$ to $\mathrm{S} 2$ an exothermic process of $25.3 \mathrm{kcal}$, see Figure 1.

(A) $\mathrm{S} 1+\mathrm{H}_{2}+\mathrm{CH}_{2} \mathrm{O} \rightarrow \mathrm{CH}_{3} \mathrm{OH}+\mathrm{S} 1$ Path[A-B1] $\Delta E_{1}=-17.0 \mathrm{kcal} / \mathrm{mol}$

(B) $\mathrm{S} 1+\mathrm{CH}_{3} \mathrm{OH} \rightarrow \mathrm{S} 2+\mathrm{H}_{2}+\mathrm{CH}_{2} \mathrm{O}$ Path[B2] $\Delta E_{2}=-8.3 \mathrm{kcal} / \mathrm{mol}$

$$
\text { (C) } \mathrm{S} 1 \rightarrow \mathrm{S} 2 \quad \Delta E_{1}+\Delta E_{2}=\Delta E_{3}=-25.3 \mathrm{kcal} / \mathrm{mol}
$$

According to this energetic profile, Path B2 would be both kinetically and thermodynamically preferred with respect to the other mechanisms explored. Thus, it is concluded that Path $\mathrm{B} 2$, proceeding without vanadyl $\mathrm{V}=\mathrm{O}$ groups, considerably lowers the energetic cost to obtain simultaneously $\mathrm{H}_{2}$ and $\mathrm{CH}_{2} \mathrm{O}$ compared to the other pathways considered. 
In the present mechanistic exercise three different patterns appear depending on the adsorption and dissociation of $\mathrm{CH}_{3} \mathrm{OH}$. Path $\mathrm{A}$ leads to less stable intermediates $(-19.0 \mathrm{kcal} / \mathrm{mol}$ for $\mathrm{MO}$ and $-15.2 \mathrm{kcal} / \mathrm{mol}$ for $\mathrm{M} 1)$ as compared with Path B1 (-16.3 kcal $/ \mathrm{mol}$ for $\mathrm{M} 3,-32.5 \mathrm{kcal} / \mathrm{mol}$ for M4). While Path $\mathrm{A}$ favors the molecular $\mathrm{CH}_{3} \mathrm{OH}$ adsorption process, the Path $\mathrm{B} 1$ strongly stabilizes the dissociative mode. Therefore, the activation barriers to overcome the rate-limiting step (associated with the $\mathrm{C}-\mathrm{H}$ bond breaking) is higher for Path B1 $(53.5 \mathrm{kcal} / \mathrm{mol})$ as compared to Path $\mathrm{A}(36.4 \mathrm{kcal} / \mathrm{mol})$. This implies that: i) $\mathrm{CH}_{3} \mathrm{OH}$ likely dissociates on the surface catalyst forming methoxide and hydroxyl groups ii) the M4 intermediate will form on the catalyst surface. This is in agreement with experimental results, see below. iii) If species M1 formed, it would react more rapidly to the products than M4.

Note that both $\mathrm{M} 1$ and $\mathrm{M} 4$ intermediates contain a $\mathrm{V}$ atom five-fold coordinated. These species have been predicted less stable than tetrahedral ones in oxidized vanadium-supported catalysts; nevertheless, the presence of penta-coordinated $V$ species interacting with water or methanol molecules has been detected by IR spectroscopy ${ }^{92-95}$. The role of five-fold coordinated V(V) species in reactivity have been analyzed in previous DFT studies. ${ }^{70}$ Our present results indicate thus that the presence of reduced $V(I I I)$ sites is thermodynamically favorable.

On the other hand, the formation of a hydride intermediate is thermodynamically favored (M7, $-20.4 \mathrm{kcal} / \mathrm{mol}$, see figure 6 ), however, its formation requires to overcome an energy barrier higher than those for the formation of M1 and M4 (32.4 kcal/mol) intermediates, making M7 intermediate less accessible in reactive processes.

The $\mathrm{CH}_{3} \mathrm{OH}$ dissociation process on $\mathrm{V}$ (III) cluster takes place with barriers significantly lower $(6.8-13.2 \mathrm{kcal} / \mathrm{mol})$ than those found on $\mathrm{V}(\mathrm{V})$ systems $(10.7-25.2 \mathrm{kcal} / \mathrm{mol}){ }^{70}$ Consequently, the $\mathrm{CH}_{3} \mathrm{OH}$ adsorption step varies considerably as function of $\mathrm{V}$ formal oxidation state, for details see Table 1; while the adsorption process is both kinetically and thermodynamically favorable at $\mathrm{V}-\mathrm{O}-\mathrm{Ti}$ and $\mathrm{V}=\mathrm{O}$ sites on $\mathrm{V}$ (III) systems, the $\mathrm{CH}_{3} \mathrm{OH}$ dissociation on supported vanadates species is experimentally suggested through $\mathrm{V}-\mathrm{O}-\mathrm{Ti}$ sites. $^{65,78,96}$ Interestingly, the reaction is found to be more favorable for $\mathrm{V}(\mathrm{III})$ 
species than for oxidized vanadium species $\mathrm{V}(\mathrm{V})$, taking place along energy barriers of $29.9 \mathrm{kcal} / \mathrm{mol}$ and $41.0 \mathrm{kcal} / \mathrm{mol}$ respectively.

The $\mathrm{CH}_{3} \mathrm{OH}$ adsorption process at $\mathrm{V}=\mathrm{O}$ sites on isolated vanadates has been discarded because it is an endothermic process yielding five-fold coordinated methoxy-intermediates. ${ }^{29}$ Moreover, we have previously demonstrated that those five-fold species are found to be potentially interesting for catalytic reactivity. ${ }^{70}$ Therefore, the formation of methoxy-intermediates in reduced $\mathrm{V}$ catalyst seems to be more favorable than in fully-oxidized systems. Likewise, the activation of $\mathrm{C}-\mathrm{H}$ bond is significantly affected. The $\mathrm{C}-\mathrm{H}$ bond activation barrier on $\mathrm{V}(\mathrm{V})$ catalyst is $\sim 41 \mathrm{kcal} / \mathrm{mol}$, while on $\mathrm{V}^{\text {III }}$ catalyst it ranges $32-55 \mathrm{kcal} / \mathrm{mol}$. This difference in energy could be attributed to the nature of the transition state involved at the $\mathrm{C}-\mathrm{H}$ activation step. On V(V) catalyst a homolytic $\mathrm{C}-\mathrm{H}$ bond breaking takes place while $\mathrm{V}$ atom is partially reduced to $\mathrm{V}$ (IV). On $\mathrm{V}$ (III) catalyst there is not electronic transfer process between methoxide group and $\mathrm{V}$ metal center and therefore the $\mathrm{C}-\mathrm{H}$ break must be necessarily heterolytic.

Interestingly, product M5 does not contain any $\mathrm{V}=\mathrm{O}$ group, instead, a $\mathrm{V}$ $\mathrm{OH}$ group is found together with one $\mathrm{V}-(\mathrm{OH})-\mathrm{Ti}$ and two $\mathrm{V}-\mathrm{O}-\mathrm{Ti}$ groups. The structure M5 is predicted to be $32.5 \mathrm{kcal} / \mathrm{mol}$ more stable than M2; both structures are similar but the latter possesses a $V=O$ group which is absent in the former. This means that reduced vanadia catalysts may not have such vanadyl groups at the exit channel, in fact, they are characteristic of oxidized $\mathrm{V}(\mathrm{V})$-containing catalysts although recently they have been proposed to exist in polyvanadate surface species. ${ }^{48}$ The absence of vanadyl $V=O$ groups in reduced vanadium catalysts is supported by experimental results: vanadiaoxidized catalysts present a characteristic Raman vibration at $\sim 1030 \mathrm{~cm}^{-1}$, assigned to $\mathrm{V}=\mathrm{O}$ groups. In the oxidation conditions, the vanadium species should be in majority at the fifth oxidation state, while the intensity of such Raman band strongly decreases. ${ }^{97,} 98$ The oxidation reaction of $\mathrm{CH}_{3} \mathrm{OH}$ proceeds with concomitant reduction of the catalyst, which decreases the oxidation of $\mathrm{V}(\mathrm{V})$ to $\mathrm{V}(\mathrm{IV}) / \mathrm{V}(\mathrm{III})$, in agreement with previous theoretical results. ${ }^{68 \text {, }}$ 70-72, 79 Surprisingly, in the analysis of the products of the $\mathrm{CH}_{3} \mathrm{OH}$ oxidation reaction only the oxidation products $\mathrm{CH}_{2} \mathrm{O}, \mathrm{CO}, \mathrm{CO}_{2}$ are reported ${ }^{65}$, but not $\mathrm{H}_{2}$. Note that catalytic systems are usually dynamic and the presence of vanadium at a different oxidation states cannot be excluded. The lack of the confirmation 
of the formation of $\mathrm{H}_{2}$ can be related to the type of the analytical technique used for a detection of the reaction products, similarly to water. Thus, our results predict the formation of $\mathrm{H}_{2}$ as product of $\mathrm{CH}_{3} \mathrm{OH}$ oxidation together with formaldehyde when a reduced $\mathrm{V}$ (III) catalyst is present.

Finally, the energy barriers for the activation of $\mathrm{O}-\mathrm{H}$ and $\mathrm{C}-\mathrm{H}$ bonds are not significantly altered by the temperature $(373 \mathrm{~K})$, nevertheless, the stability of adducts (M0, M2, M3, M5, and M6) and methoxy-intermediates (M1, M4 and M7) and their corresponding transition states are strongly affected. Thus, on $\mathrm{V}$ (III) catalysts, the adsorption of $\mathrm{CH}_{3} \mathrm{OH}$ is expected to be an exergonic process on both $\mathrm{V}=\mathrm{O}$ and $\mathrm{V}-\mathrm{O}-\mathrm{Ti}$ sites, yielding to the formation of five-fold coordinated methoxy-intermediates which seem to be both kinetically and thermodynamically favorable. Likewise, the $\mathrm{H}_{2}$ and $\mathrm{CH}_{2} \mathrm{O}$ desorption is expected to be an exergonic process.

\section{Conclusions}

The present theoretical work adds a new insight into the gas phase mechanisms of the dehydrogenation of $\mathrm{CH}_{3} \mathrm{OH}$ to be compared with supported reduced vanadium oxides. The results show that the methanol adsorption on $\mathrm{V}$ (III) systems sites is thermodynamically favourable, while methanol dissociation gives rise to stable five-fold coordinates $V(I I I)$ methoxyintermediates. The most likely intermediate does not contain vanadyl $V=O$ groups. As result, the role of the catalyst is first to dissociate the $\mathrm{CH}_{3} \mathrm{OH}$ molecule and second to improve the gas-phase mechanism by stabilizing the transition state. In fact, one of the reaction pathway (Path B2) to obtain $\mathrm{H}_{2}$ and $\mathrm{CH}_{2} \mathrm{O}$ is found to proceed below the reference energy. The $\mathrm{CH}_{3} \mathrm{OH}$ adsorption process may also bring about the formation of hydride intermediates, although kinetically less favourable, they may present an interesting catalytic activity. The overall methanol oxidation process is found to be more favourable over V(III) than on $\mathrm{V}(\mathrm{V})$ species.

\section{Acknowledgments}

The authors are grateful to Generalitat Valenciana for Prometeoll/2014/022 and ACOMP/2015/1202, to Universitat Jaume I for project 
UJI-B2016-25, and to Ministerio de Economía y Competitividad (Spain) for project CTQ2015-65207-P. The authors also thank the Servei d'Informàtica, Universitat Jaume I, for computational facilities. MC is grateful to Institut Universitaire de France for a junior position and GENCI project Grants 2016x2016082131, 2017- x2017082131 for computing time.

\section{Notes}

The authors declare no competing financial interest.

\section{References}

(1) Olah, G. A. Beyond Oil and Gas: The Methanol Economy. Angew. Chem. Int. Ed. 2005, 44, 2636-2639.

(2) Olah, G. A.; Prakash, G. K. S.; Goeppert, A. Anthropogenic Chemical Carbon Cycle for a Sustainable Future. J. Am. Chem. Soc. 2011, 133, 12881-12898.

(3) Pfeifenschneider, J.; Brautaset, T.; Wendisch, V. F. Methanol as Carbon Substrate in the Bio-Economy: Metabolic Engineering of Aerobic Methylotrophic Bacteria for Production of Value-Added Chemicals. Biofuel Bioprod. Bior. 2017, 11, 719-731.

(4) Hohn, K. L.; Lin, Y.-C. Catalytic Partial Oxidation of Methanol and Ethanol for Hydrogen Generation. Chemsuschem 2009, 2, 927-940.

(5) Badlani, M.; Wachs, I. E. Methanol: a "Smart" Chemical Probe Molecule. Catal. Lett. 2001, 75, 137-149.

(6) Centi, G.; Cavani, F.; Trifirò, F., Selective oxidation by heterogeneous catalysis. Kluwer Academic/Plenum Publishers: New York, 2001

(7) Weckhuysen, B. M.; Keller, D. E. Chemistry, Spectroscopy and the Role of Supported Vanadium Oxides in Heterogeneous Catalysis. Catal. Today 2003, 78, 2546.

(8) Natte, K.; Neumann, H.; Beller, M.; Jagadeesh, R. V. Transition-MetalCatalyzed Utilization of Methanol as a C1 Source in Organic Synthesis. Angew. Chem. Int. Ed. 2017, 56, 6384-6394.

(9) Nielsen, M.; Alberico, E.; Baumann, W.; Drexler, H.-J.; Junge, H.; Gladiali, S.; Beller, M. Low-Temperature Aqueous-Phase Methanol Dehydrogenation to Hydrogen and Carbon Dioxide. Nature 2013, 495, 85-89.

(10) Norskov, J. K.; Bligaard, T.; Rossmeisl, J.; Christensen, C. H. Towards the Computational Design of Solid Catalysts. Nat. Chem. 2009, 1, 37-46.

(11) Norskov, J. K.; Christensen, C. H. Chemistry - Toward Efficient Hydrogen Production at Surfaces. Science 2006, 312, 1322-1323.

(12) A. Gamez, J.; Corral, I.; Mo, O.; Yanez, M. Unexpected Gas-Phase Ion Chemistry Results Unraveled by Computational Chemistry. Curr. Org. Chem. 14, 16001611.

(13) Brea, O.; Yanez, M.; Mo, O.; Lamsabhi, A. On the Stability of $\left[(\text { uracil })_{2}-\mathrm{Cu}\right]^{2+}$ Complexes in the Gas Phase. Different Pathways for the Formation of [(uracilH)(uracil)-Cu] monocations. Org. Biomol. Chem. 2013, 11, 3862-3870.

(14) Eizaguirre, A.; Mo, O.; Yanez, M.; Salpin, J. Y.; Tortajada, J. Modelling PeptideMetal Dication Interactions: Formamide- $\mathrm{Ca}^{2+}$ Reactions in the Gas Phase. Org. Biomol. Chem. 2012, 10, 7552-7561.

(15) Eizaguirre, A.; Mo, O.; Yanez, M.; Tortajada, J.; Salpin, J. Y. Unimolecular Reactivity of the [Urea-Sr] $]^{2+}$ Complex, a Metastable Dication in the Gas Phase: An Experimental and Theoretical Perspective. J. Phys. Chem. B 2013, 117, 2088-2095. 
(16) Hurtado, M.; Lamsabhi, A. M.; Mo, O.; Yanez, M.; Guillemin, J. C. On the Origin of the Enhanced Acidity of Chalcocyclopentadienes (Cyclopentadiene Chalcogenols) in the Gas Phase. Chemphyschem 2012, 13, 1167-1172.

(17) Hurtado, M.; Monte, M.; Lamsabhi, A. M.; Yanez, M.; Mo, O.; Salpin, J. Y. Modeling Interactions between an Amino Acid and a Metal Dication: CysteineCalcium(II) Reactions in the Gas Phase. Chempluschem 2013, 78, 1124-1133.

(18) Montero-Campillo, M. M.; Mo, O.; Yanez, M.; Benidar, A.; Rouxel, C.; Kerisit, N.; Trolez, Y.; Guillemin, J. C. Gas-Phase Infrared Spectroscopy of Substituted Cyanobutadiynes: Roles of the Bromine Atom and Methyl Group as Substituents. Chemphyschem 2016, 17, 1018-1024.

(19) Gonzalez-Navarrete, P.; Schlangen, M.; Schwarz, H. Gas-Phase Reactions of Cationic Molybdenum and Tungsten Monoxide with Ethanol: a Combined

Experimental/Computational Exercise. Struct. Chem. 2017, 28, 403-413.

(20) Gonzalez-Navarrete, P.; Schlangen, M.; Wu, X. N.; Schwarz, H. Unravelling Mechanistic Aspects of the Gas-Phase Ethanol Conversion: An Experimental and Computational Study on the Thermal Reactions of $\mathrm{MO}_{2}{ }^{+}(\mathrm{M}=\mathrm{Mo}, \mathrm{W})$ with Ethanol. Chem. Eur. J 2016, 22, 3077-3083.

(21) Sui, H. G.; Zhang, F. Y.; Hou, F.; Zhao, L. M.; Guo, W. Y.; Yao, J. Theoretical Investigation of the Methanol Decomposition by $\mathrm{Fe}^{+}$and $\mathrm{Fe}\left(\mathrm{C}_{2} \mathrm{H}_{4}\right)^{+}$: A PI-Type Ligand Effect. J. Phys. Chem. A 2015, 119, 10204-10211.

(22) Cao, Y. L.; Zhao, X.; Tang, Z. C.; Xin, B.; Xiong, S. X. Gas-Phase Reactions of $\mathrm{V}^{+}$and $\mathrm{VO}^{+}$with Methanol. Int. J. Mod. Phys. B 2005, 19, 2693-2698.

(23) Dong, F.; Heinbuch, S.; Xie, Y.; Rocca, J. J.; Bernstein, E. R. Reactions of Neutral Vanadium Oxide Clusters with Methanol. J. Phys. Chem. A 2009, 113, 30293040.

(24) Engeser, M.; Schröder, D.; Schwarz, H. Dehydration and Dehydrogenation of Alcohols with Mononuclear Cationic Vanadium Oxides in the Gas Phase and Energetics of $\mathrm{VO}_{n} \mathrm{H}^{0 /+}(\mathrm{n}=2,3)$. Eur. J. Inorg. Chem. 2007, 2454-2464.

(25) Feyel, S.; Scharfenberg, L.; Daniel, C.; Hartl, H.; Schroder, D.; Schwarz, H. Dehydrogenation of Methanol by Vanadium Oxide and Hydroxide Cluster Cations in the Gas Phase. J. Phys. Chem. A 2007, 111, 3278-3286.

(26) Feyel, S.; Schröder, D.; Schwarz, H. Pronounced Cluster-Size Effects: GasPhase Reactivity of Bare Vanadium Cluster Cations $\mathrm{V}_{\mathrm{n}}^{+}(\mathrm{n}=1-7)$ Toward Methanol. J. Phys. Chem. A 2009, 113, 5625-5632.

(27) Fialko, E. F.; Kikhtenko, A. V.; Goncharov, V. B. Molybdenum Oxide Cluster lons in the Gas Phase: Reactions with Small Alcohols. Organometallics 1998, 17, $25-$ 31.

(28) Goncharov, V. B. Reactions of Neutral and Charged Molybdenum Oxide Clusters with Low-Molecular-Weight Alcohols in a Gas Phase Studied by lon Cyclotron Resonance. Kinet. Catal. 2003, 44, 499-512.

(29) Gracia, L.; Gonzalez-Navarrete, P.; Calatayud, M.; Andres, J. A DFT Study of Methanol Dissociation on Isolated Vanadate Groups. Catal. Today 2008, 139, 214-220.

(30) Harris, B. L.; Waters, T.; Khairallah, G. N.; O'Hair, R. A. J. Gas-Phase

Reactions of $\mathrm{VO}_{2}(\mathrm{OH})_{2}^{-}$and $\mathrm{V}_{2} \mathrm{O}_{5}(\mathrm{OH})^{-}$with Methanol: Experiment and Theory. J. Phys. Chem. A 2013, 117, 1124-1135.

(31) Jackson, P.; Fisher, K. J.; Willett, G. D. The Catalytic Activation of Primary Alcohols on Niobium Oxide Surfaces Unraveled: the Gas Phase Reactions of $\mathrm{Nb}_{x} \mathrm{O}_{\mathrm{y}}$ Clusters with Methanol and Ethanol. Chem. Phys. 2000, 262, 179-187.

(32) Justes, D. R.; Moore, N. A.; Castleman Jr., A. W. Reactions of Vanadium and Niobium Oxides with Methanol. J. Phys. Chem. B 2004, 108, 3855-3862.

(33) Michelini, M. d. C.; Marcalo, J.; Russo, N.; Gibson, J. K. Gas-Phase Reactions of Uranate lons, $\mathrm{UO}_{2}{ }^{-}, \mathrm{UO}_{3}{ }^{-}, \mathrm{UO}_{4}{ }^{-}$, and $\mathrm{UO}_{4} \mathrm{H}^{-}$, with Methanol: a Convergence of Experiment and Theory. Inorg. Chem. 2010, 49, 3836-3850.

(34) Romanyshyn, Y.; Guimond, S.; Kuhlenbeck, H.; Kaya, S.; Blum, R. P.; Niehus, H.; Shaikhutdinov, S.; Simic-Milosevic, V.; Nilius, N.; Freund, H. J.; Ganduglia- 
Pirovano, M. V.; Fortrie, R.; Dobler, J.; Sauer, J. Selectivity in Methanol Oxidation as Studied on Model Systems Involving Vanadium Oxides. Top. Catal. 2008, 50, 106-115. (35) Schlangen, M.; Schwarz, H. Selective C-H versus O-H Bond Activation of $\mathrm{CH}_{3} \mathrm{OH}$ upon Electrospraying Methanolic Solutions of $\mathrm{MX}_{2}(\mathrm{M}=\mathrm{Fe}, \mathrm{Co}, \mathrm{Ni} ; \mathrm{X}=\mathrm{Br}, \mathrm{I})$ : $\mathrm{A}$ DFT Study. Chemcatchem 2010, 2, 799-802.

(36) Schröder, D.; Wesendrup, R.; Schalley, C. A.; Zummack, W.; Schwarz, H. GasPhase Reactions of Aliphatic Alcohols with bare FeO'. Helvetica Chimica Acta 1996, 79, 123-132.

(37) Waters, T.; Khairallah, G. N.; Wimala, S. A. S. Y.; Ang, Y. C.; O'Hair, R. A. J.; Wedd, A. G. Mononuclear Metavanadate Catalyses Gas Phase Oxidation of Methanol to formaldehyde Employing Dioxygen as the Terminal Oxidant. Chem Commun 2006, 4503-4505.

(38) Armentrout, P. B. Reactions and Thermochemistry of Small Transition Metal Cluster lons. Annu. Rev. Phys. Chem. 2001, 52, 423-461.

(39) Muylaert, I.; Van Der Voort, P. Supported Vanadium Oxide in Heterogeneous Catalysis: Elucidating the Structure-Activity Relationship with Spectroscopy. Phys. Chem. Chem. Phys. 2009, 11, 2826-2832.

(40) Agnoli, S.; Castellarin-Cudia, C.; Sambi, M.; Surnev, S.; Ramsey, M. G.; Granozzi, G.; Netzer, F. P. Vanadium on $\mathrm{TiO}_{2}(110)$ : Adsorption Site and Sub-Surface Migration. Surf. Sci. 2003, 546, 117-126.

(41) Surnev, S.; Ramsey, M. G.; Netzer, F. P. Vanadium Oxide Surface Studies. Prog. Surf. Sci. 2003, 73, 117-165.

(42) Wachs, I. E.; Weckhuysen, B. M. Structure and Reactivity of Surface Vanadium Oxide Species on Oxide Supports. Appl. Catal. A-Gen. 1997, 157, 67-90.

(43) Lee, E. L.; Wachs, I. E. Molecular Design and In Situ Spectroscopic Investigation of Multilayered Supported $\mathrm{M}_{1} \mathrm{O}_{x} / \mathrm{M}_{2} \mathrm{O}_{x} / \mathrm{SiO}_{2}$ Catalysts. J. Phys. Chem. $C$ 2008, 112, 20418-20428.

(44) Wachs, I. E. The Generality of Surface Vanadium Oxide Phases in Mixed Oxide catalysts. Appl. Catal. A-Gen. 2011, 391, 36-42.

(45) Banares, M. A.; Wachs, I. E. Molecular Structures of Supported Metal Oxide Catalysts Under Different Environments. J. Raman Spectrosc. 2002, 33, 359-380.

(46) Wachs, I. E. Catalysis Science of Supported Vanadium Oxide Catalysts. Dalton Trans. 2013, 42, 11762-11769.

(47) Beck, B.; Harth, M.; Hamilton, N. G.; Carrero, C.; Uhlrich, J. J.; Trunschke, A.; Shaikhutdinov, S.; Schubert, H.; Freund, H.-J.; Schlögl, R.; Sauer, J.; Schomäcker, R. Partial Oxidation of Ethanol on Vanadia Catalysts on Supporting Oxides with Different Redox Properties Compared to Propane. J. Catal. 2012, 296, 120-131.

(48) Artiglia, L.; Agnoli, S.; Vittadini, A.; Verdini, A.; Cossaro, A.; Floreano, L.; Granozzi, G. Atomic Structure and Special Reactivity Toward Methanol Oxidation of Vanadia Nanoclusters on $\mathrm{TiO}_{2}(110)$. J. Am. Chem. Soc. 2013, 135, 17331-17338.

(49) Deshlahra, P.; Igesia, E. Methanol Oxidative Dehydrogenation on Oxide Catalysts: Molecular and Dissociative Routes and Hydrogen Addition Energies as Descriptors of Reactivity. J. Phys. Chem. C 2014, 118, 26115-26129.

(50) Kropp, T.; Paier, J.; Sauer, J. Oxidative Dehydrogenation of Methanol at CeriaSupported Vanadia Oligomers. J. Catal. 2017, 352, 382-387.

(51) Li, Y.; Wei, Z. H.; Gao, F.; Kovarik, L.; Peden, C. H. F.; Wang, Y. Effects of $\mathrm{CeO}_{2}$ Support Facets on $\mathrm{VO}_{\mathrm{x}} / \mathrm{CeO}_{2}$ Catalysts in Oxidative Dehydrogenation of Methanol. J. Catal. 2014, 315, 15-24.

(52) Price, S. P.; Tong, X.; Ridge, C.; Neilson, H. L.; Buffon, J. W.; Robins, J.; Metiu, H.; Bowers, M. T.; Buratto, S. K. Catalytic Oxidation of Methanol to Formaldehyde by Mass-Selected Vanadium Oxide Clusters Supported on a $\mathrm{TiO}_{2}(110)$ Surface. J. Phys. Chem. A 2014, 118, 8309-8313.

(53) Tranca, D. C.; Keil, F. J.; Tranca, I.; Calatayud, M.; Dzwigaj, S.; Trejda, M.; Tielens, F. Methanol Oxidation to Formaldehyde on VSiBEA Zeolite: A Combined 
DFT/vdW/Transition Path Sampling and Experimental Study. J. Phys. Chem. C 2015, 119, 13619-13631.

(54) Chen, W. L.; Liu, H. C. Relationship between the Structures of Metal Oxide Catalysts and Their Properties in Selective Oxidation of Methanol. Acta Phys-Chim. Sin. 2012, 28, 2315-2326.

(55) Fievez, T.; Weckhuysen, B. M.; Geerlings, P.; De Proft, F. Chemical Reactivity Indices as a Tool for Understanding the Support-Effect in Supported Metal Oxide Catalysts. J. Phys. Chem. C 2009, 113, 19905-19912.

(56) Kropp, T.; Paier, J.; Sauer, J. Support Effect in Oxide Catalysis: Methanol Oxidation on Vanadia/Ceria. J. Am. Chem. Soc. 2014, 136, 14616-14625.

(57) Vining, W. C.; Strunk, J.; Bell, A. T. Investigation of the Structure and Activity of $\mathrm{VO}_{x} / \mathrm{ZrO}_{2} / \mathrm{SiO}_{2}$ Catalysts for Methanol Oxidation to Formaldehyde. J. Catal. 2011, 281, 222-230.

(58) Vining, W. C.; Strunk, J.; Bell, A. T. Investigation of the Structure and Activity of $\mathrm{VO}_{\mathrm{x}} / \mathrm{CeO}_{2} / \mathrm{SiO}_{2}$ Catalysts for Methanol Oxidation to Formaldehyde. J. Catal. 2012, 285, 160-167.

(59) Zeng, D. L.; Liu, S. L.; Wang, G. H.; Chen, H. X.; Xu, J.; Deng, F. Effect of Surface Acid Properties of Modified $\mathrm{VO}_{\times} / \mathrm{Al}_{2} \mathrm{O}_{3}$ Catalysts on Methanol Selective Oxidation. Catal. Lett. 2013, 143, 624-629.

(60) Bronkema, J. L.; Bell, A. T. Mechanistic Studies of Methanol Oxidation to Formaldehyde on Isolated Vanadate Sites Supported on MCM-48. J. Phys. Chem. C 2007, 111, 420-430.

(61) Bronkema, J. L.; Leo, D. C.; Bell, A. T. Mechanistic Studies of Methanol Oxidation to Formaldehyde on Isolated Vanadate Sites Supported on High Surface Area Anatase. J. Phys. Chem. C 2007, 111, 14530-14540.

(62) Burcham, L. J.; Briand, L. E.; Wachs, I. E. Quantification of Active Sites for the Determination of Methanol Oxidation Turn-Over Frequencies using Methanol Chemisorption and in Situ Infrared Techniques. 1. Supported Metal Oxide Catalysts. Langmuir 2001, 17, 6164-6174.

(63) Burcham, L. J.; Briand, L. E.; Wachs, I. E. Quantification of Active Sites for the Determination of Methanol Oxidation Turn-Over Frequencies using Methanol Chemisorption and in Situ Infrared Techniques. 2. Bulk Metal Oxide Catalysts. Langmuir 2001, 17, 6175-6184.

(64) Burcham, L. J.; Wachs, I. E. The origin of the support effect in supported metal oxide catalysts: in situ infrared and kinetic studies during methanol oxidation. Catal.

Today 1999, 49, 467-484.

(65) Deo, G.; Wachs, I. E. Reactivity of Supported Vanadium-Oxide Catalysts - the Partial Oxidation of Methanol. J. Catal. 1994, 146, 323-334.

(66) Deo, G.; Wachs, I. E. Effect of Additives on the Structure and Reactivity of the Surface Vanadium-Oxide Phase in $\mathrm{V}_{2} \mathrm{O}_{5} \mathrm{TiO}_{2}$ Catalysts. J. Catal. 1994, 146, 335-345.

(67) Ding, X. L.; Xue, W.; Ma, Y. P.; Zhao, Y. X.; Wu, X. N.; He, S. G. Theoretical Investigation of the Selective Oxidation of Methanol to Formaldehyde on Vanadium Oxide Species Supported on Silica: Umbrella Model. J. Phys. Chem. C 2010, 114, 3161-3169.

(68) Dobler, J.; Pritzsche, M.; Sauer, J. Oxidation of Methanol to Formaldehyde on Supported Vanadium Oxide Catalysts Compared to Gas Phase Molecules. J. Am. Chem. Soc. 2005, 127, 10861-10868.

(69) Faraldos, M.; Banares, M. A.; Anderson, J. A.; Hu, H. C.; Wachs, I. E.; Fierro, J. L. G. Comparison of Silica-Supported $\mathrm{MoO}_{3}$ and $\mathrm{V}_{2} \mathrm{O}_{5}$ Catalysts in the Selective Partial Oxidation of Methane. J. Catal. 1996, 160, 214-221.

(70) Gonzalez-Navarrete, P.; Gracia, L.; Calatayud, M.; Andres, J. Unraveling the Mechanisms of the Selective Oxidation of Methanol to Formaldehyde in Vanadia Supported on Titania Catalyst. J. Phys. Chem. C 2010, 114, 6039-6046. 
(71) Goodrow, A.; Bell, A. T. A Theoretical Investigation of the Selective Oxidation of Methanol to Formaldehyde on Isolated Vanadate Species Supported on Silica. J. Phys. Chem. C 2007, 111, 14753-14761.

(72) Goodrow, A.; Bell, A. T. A Theoretical Investigation of the Selective Oxidation of Methanol to Formaldehyde on Isolated Vanadate Species Supported on Titania. J. Phys. Chem. C 2008, 112, 13204-13214.

(73) Goodrow, A.; Bell, A. T.; Head-Gordon, M. Are Spin-Forbidden Crossings a Bottleneck in Methanol Oxidation? J. Phys. Chem. C 2009, 113, 19361-19364.

(74) Khaliullin, R. Z.; Bell, A. T. A Density Functional Theory Study of the Oxidation of Methanol to Formaldehyde over Vanadia Supported on Silica, Titania, and Zirconia. J. Phys. Chem. B 2002, 106, 7832-7838.

(75) Rozanska, X.; Sauer, J. Oxidative Conversion of C1-C3 alkanes by Vanadium Oxide Catalysts. DFT Results and their Accuracy. Int. J. Quantum Chem. 2008, 108, 2223-2229.

(76) van Lingen, J. N. J.; Gijzernan, O. L. J.; Weckhuysen, B. M.; van Lenthe, J. H. On the Umbrella Model for Supported Vanadium Oxide Catalysts. J. Catal. 2006, 239, 34-41.

(77) Vining, W. C.; Goodrow, A.; Strunk, J.; Bell, A. T. An Experimental and Theoretical Investigation of the Structure and Reactivity of Bilayered $\mathrm{VO}_{\mathrm{x}} / \mathrm{TiO}_{\mathrm{x}} / \mathrm{SiO}_{2}$ Catalysts for Methanol Oxidation. J. Catal. 2010, 270, 163-171.

(78) Wachs, I. E.; Briand, L. E.; Jehng, J. M.; Burcham, L.; Gao, X. T. Molecular Structure and Reactivity of the Group V Metal Oxides. Catal. Today 2000, 57, 323-330. (79) Gonzalez-Navarrete, P.; Gracia, L.; Calatayud, M.; Andres, J. Density Functional Theory Study of the Oxidation of Methanol to Formaldehyde on a Hydrated Vanadia Cluster. J. Comput. Chem. 2010, 31, 2493-2501.

(80) Engeser, M.; Schroder, D.; Schwarz, H. Gas-Phase Dehydrogenation of Methanol with Mononuclear Vanadium-Oxide Cations. Chem. Eur. J 2005, 11, 59755987.

(81) Gaussian 09, Revision B.01, M. J. Frisch, G. W. T., H. B. Schlegel, G. E. Scuseria, ; M. A. Robb, J. R. C., G. Scalmani, V. Barone, B. Mennucci, ; G. A. Petersson, H. N., M. Caricato, X. Li, H. P. Hratchian, ; A. F. Izmaylov, J. B., G. Zheng, J. L. Sonnenberg, M. Hada, ; M. Ehara, K. T., R. Fukuda, J. Hasegawa, M. Ishida, T. Nakajima, ; Y. Honda, O. K., H. Nakai, T. Vreven, J. A. Montgomery, Jr., ; J. E. Peralta, F. O., M. Bearpark, J. J. Heyd, E. Brothers, ; K. N. Kudin, V. N. S., T. Keith, R. Kobayashi, J. Normand, ; K. Raghavachari, A. R., J. C. Burant, S. S. lyengar, J. Tomasi, ; M. Cossi, N. R., J. M. Millam, M. Klene, J. E. Knox, J. B. Cross, ; V. Bakken, C. A., J. Jaramillo, R. Gomperts, R. E. Stratmann, ; O. Yazyev, A. J. A., R. Cammi, C. Pomelli, J. W. Ochterski, ; R. L. Martin, K. M., V. G. Zakrzewski, G. A. Voth, ; P. Salvador, J. J. D., S. Dapprich, A. D. Daniels, ; O. Farkas, J. B. F., J. V. Ortiz, J. Cioslowski, ; and D. J. Fox, G., Inc., Wallingford CT, 2010.

(82) Becke, A. D. Density-Functional Exchange-Energy Approximation with Correct Asymptotic-Behavior. Phys. Rew. A 1988, 38, 3098-3100.

(83) Becke, A. D. Density-Functional Thermochemistry .3. The Role of Exact Exchange. J. Chem. Phys. 1993, 98, 5648-5652.

(84) Lee, C. T.; Yang, W. T.; Parr, R. G. Development of the Colle-Salvetti Correlation-Energy Formula into a Functional of the Electron-Density. Phys. Rew. $B$ 1988, 37, 785-789.

(85) Frisch, M. J.; Pople, J. A.; Binkley, J. S. Self-Consistent Molecular-Orbital Methods .25. Supplementary Functions for Gaussian-Basis Sets. Journal of Chem. Phys. 1984, 80, 3265-3269.

(86) Borowski, T.; Szczepanik, W.; Chruszcz, M.; Broclawik, E. First-principle Calculations for the Active Centers in Vanadium-Containing Chloroperoxidase and its Functional Models: Geometrical and Spectral Properties. Int. J. Quantum Chem. 2004, 99, 864-875. 
(87) Jakubikova, E.; Bernstein, E. R. Reactions of Sulfur Dioxide with Neutral Vanadium Oxide Clusters in the Gas Phase. I. Density Functional Theory Study. J. Phys. Chem. A 2007, 111, 13339-13346.

(88) McQuarrie, D. A., Statistical thermodynamics. Harper \& Row: New York, 1973

(89) Ochterski, J. W., Thermochemistry in Gaussian. Gaussian, Inc.: Pittsburgh, PA, 2000.

(90) Schroder, D.; Shaik, S.; Schwarz, H. Two-State Reactivity as a New Concept in Organometallic Chemistry. Acc. Chem. Res. 2000, 33, 139-145.

(91) Wang, G. J.; Su, J.; Gong, Y.; Zhou, M. F.; Li, J. Chemistry on Single Atoms: Spontaneous Hydrogen Production from Reactions of Transition-Metal Atoms with Methanol at Cryogenic Temperatures. Angew. Chem. Int. Ed. 2010, 49, 1302-1305. (92) Busca, G. On the Mechanism of Methanol Oxidation over Vanadia-Based Catalysts - A FTIR Study of the Adsorption of Methanol, Formaldehyde and FormicAcid on Vanadia and Vanadia-Silica. J. Mol. Catal. 1989, 50, 241-249.

(93) Busca, G. Differentiation of Mono-Oxo and Polyoxo and of Monomeric and Polymeric Vanadate, Molybdate and Tungstate Species in Metal Oxide Catalysts by IR and Raman Spectroscopy. J. Raman Spectrosc. 2002, 33, 348-358.

(94) Busca, G.; Lietti, L.; Ramis, G.; Berti, F. Chemical and Mechanistic Aspects of the Selective Catalytic Reduction of $\mathrm{NO}_{x}$ by Ammonia over Oxide Catalysts: A Review. Appl. Catal. B-Environ. 1998, 18, 1-36.

(95) Lietti, L.; Ramis, G.; Berti, F.; Toledo, G.; Robba, D.; Busca, G.; Forzatti, P. Chemical, Structural and Mechanistic Aspects on $\mathrm{NO}_{\mathrm{x}} \mathrm{SCR}$ over Commercial and Model Oxide Catalysts. Catal. Today 1998, 42, 101-116.

(96) Korhonen, S. T.; Banares, M. A.; Fierro, J. L. G.; Krause, A. O. I. Adsorption of Methanol as a Probe for Surface Characteristics of Zirconia-, Alumina-, and Zirconia/Alumina-Supported Chromia Catalysts. Catal. Today 2007, 126, 235-247. (97) Gao, X. T.; Bare, S. R.; Fierro, J. L. G.; Wachs, I. E. Structural Characteristics and Reactivity/Reducibility Properties of Dispersed and Bilayered $\mathrm{V}_{2} \mathrm{O}_{5} / \mathrm{TiO}_{2} / \mathrm{SiO}_{2}$ catalysts. J. Phys. Chem. B 1999, 103, 618-629.

(98) Wang, C. B.; Cai, Y. P.; Wachs, I. E. Reaction-Induced Spreading of Metal Oxides onto Surfaces of Oxide Supports during Alcohol Oxidation: Phenomenon, Nature, and Mechanisms. Langmuir 1999, 15, 1223-1235. 

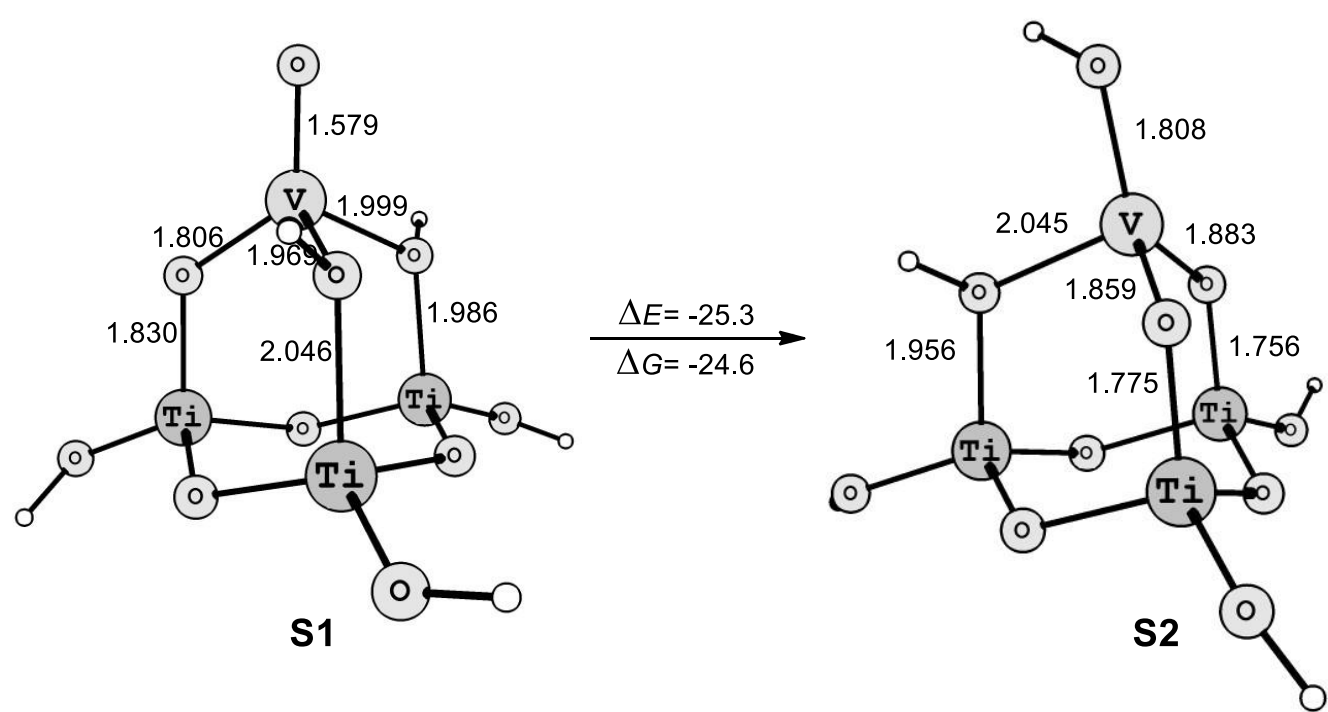

Figure 1. Models for the reduced vanadium oxide species supported on $\mathrm{TiO}_{2}$ catalyst. Distances in angstrom and energy in $\mathrm{kcal} / \mathrm{mol}$. 


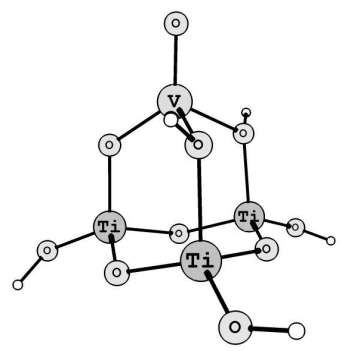

Methanol Adsorption

a)

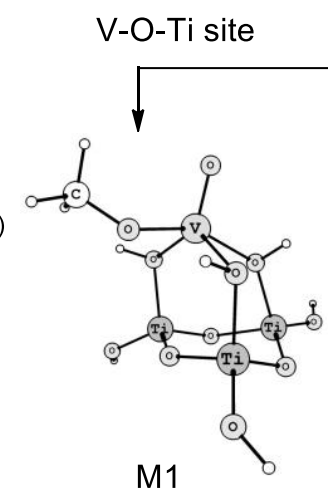

$\Delta E=-15.2 \mathrm{kcal} / \mathrm{mol}$

$\Delta G=-1.2 \mathrm{kcal} / \mathrm{mol}$

$\Delta E^{\dagger}=6.8 \mathrm{kcal} / \mathrm{mol}$ $\Delta G^{\dagger}=7.6 \mathrm{kcal} / \mathrm{mol}$

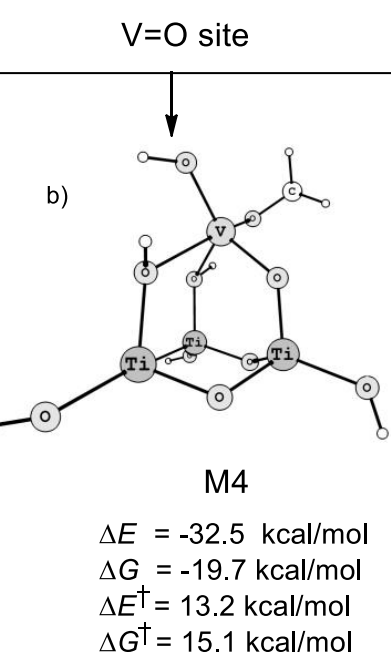

V site

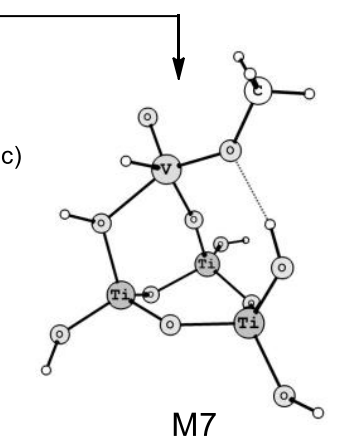

$\Delta E=-20.4 \mathrm{kcal} / \mathrm{mol}$ $\Delta G=-6.7 \mathrm{kcal} / \mathrm{mol}$ $\Delta E^{\dagger}=32.4 \mathrm{kcal} / \mathrm{mol}$ $\Delta G^{\dagger}=32.2 \mathrm{kcal} / \mathrm{mol}$

Figure 2. Structures at $B 3 L Y P / 6-311 \mathrm{G}(2 \mathrm{~d}, \mathrm{p})$ level for the $\mathrm{CH}_{3} \mathrm{OH}$ adsorption process on a) $\mathrm{V}-\mathrm{O}-\mathrm{Ti}$ site b) $\mathrm{V}=\mathrm{O}$ site c) vanadium site. The $\Delta G$ values are calculated at $373 \mathrm{~K}$. $\Delta G^{\dagger}$ and $\Delta E^{\dagger}$ values correspond to the relative free activation energy and activation energy of the transition state, respectively. 

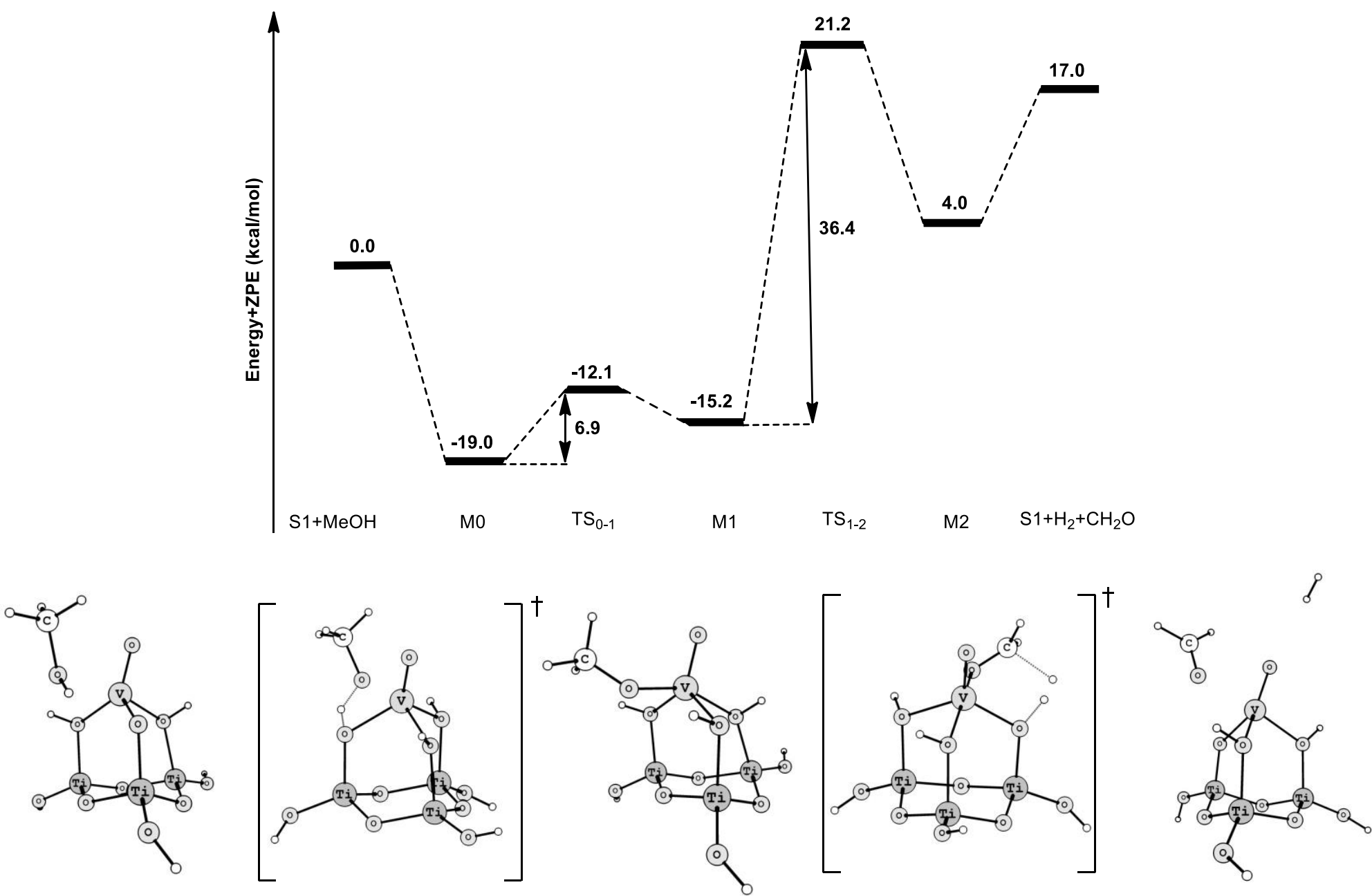

Mo

$\mathrm{TS}_{0-1}$

M1

$\mathrm{TS}_{1-2}$

M2

Figure 3. Total energy profiles at the B3LYP/6-311G(2d,p) level for Path A relative to the entrance channel S1+ $\underline{\mathrm{CH}_{3}} \underline{\mathrm{OH}}$. 


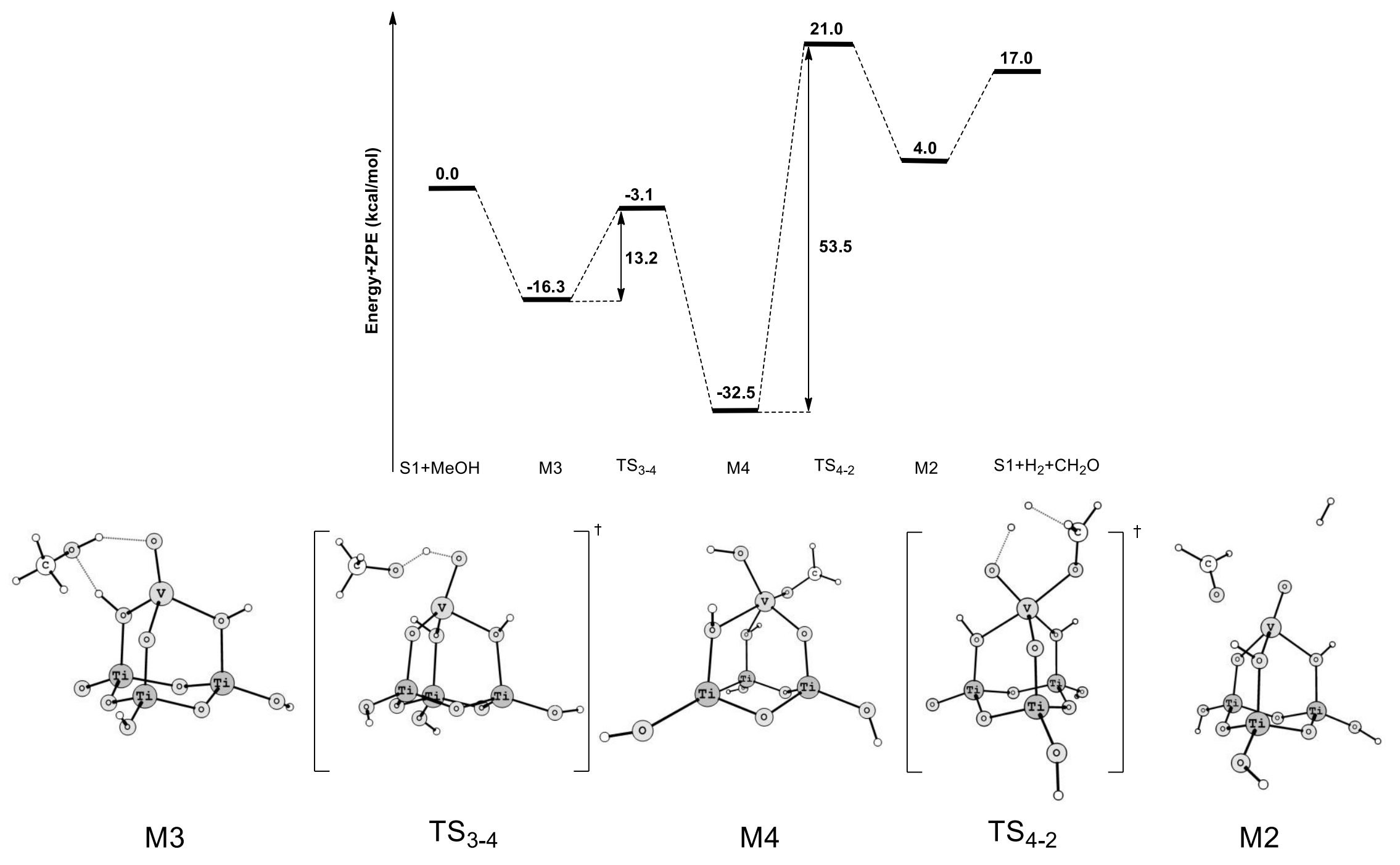

Figure 4. Total energy profiles at the B3LYP/6-311G(2d,p) level for Path B1 relative to the entrance channel S1 $+\underline{\mathrm{CH}}_{3} \underline{\mathrm{OH}}$. 

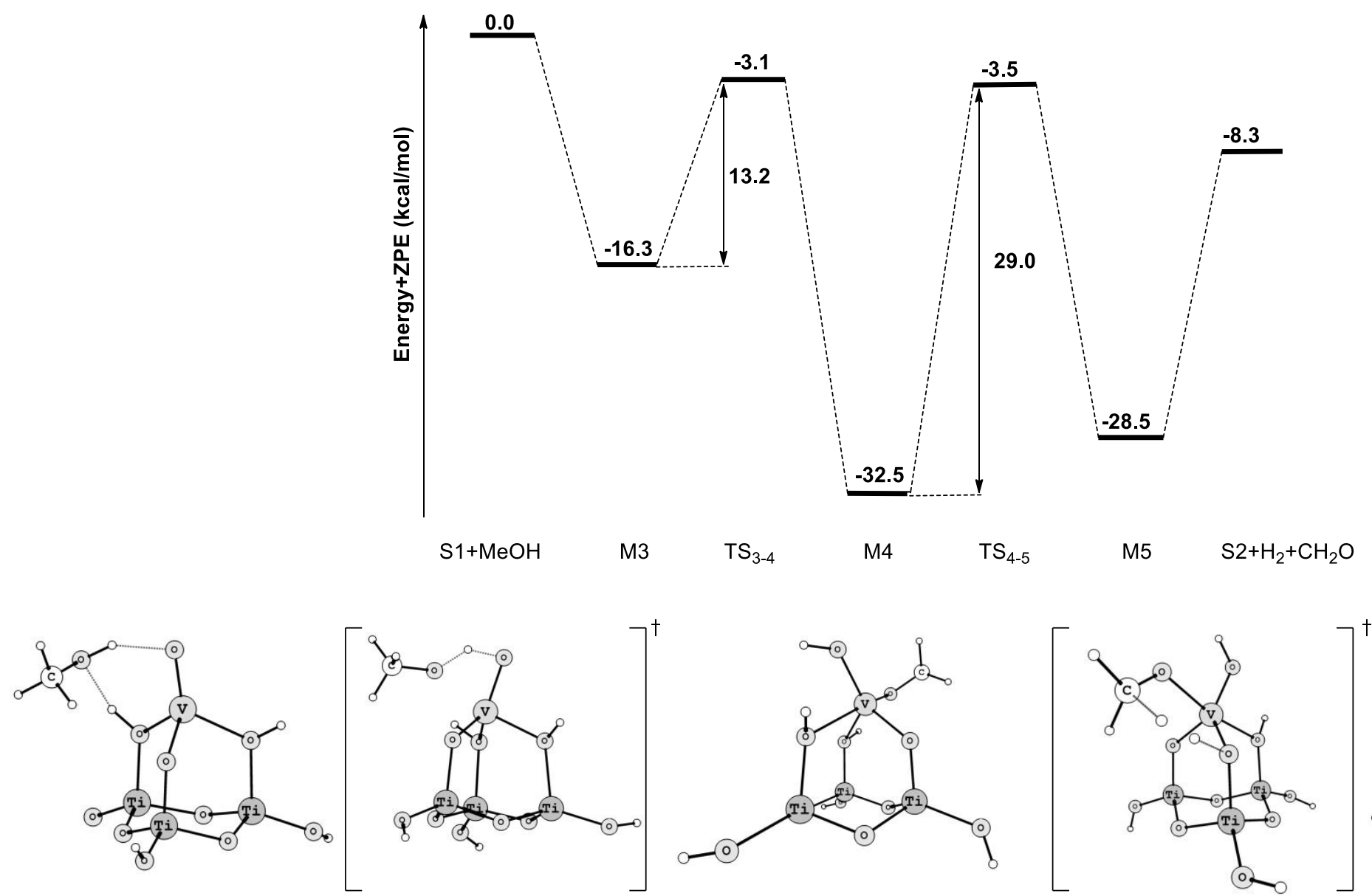

M3

$\mathrm{TS}_{3-4}$

M4

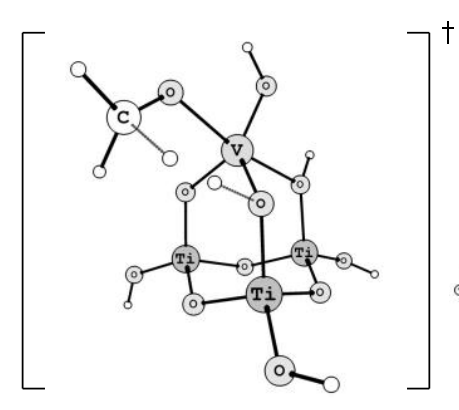

$\mathrm{TS}_{4-5}$

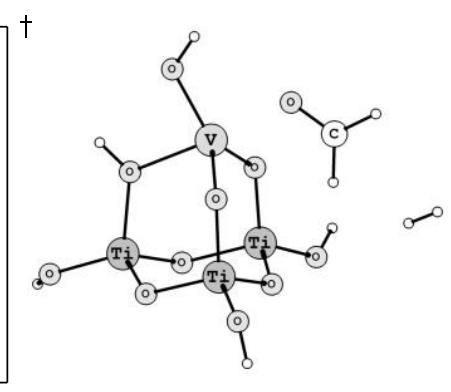

M5

Figure 5. Total energy profiles at the B3LYP/6-311G(2d,p) level for Path $\mathrm{B} 2$ relative to the entrance channel $\mathrm{S} 1+\underline{\mathrm{CH}} 3 \underline{\underline{O H}}$. 


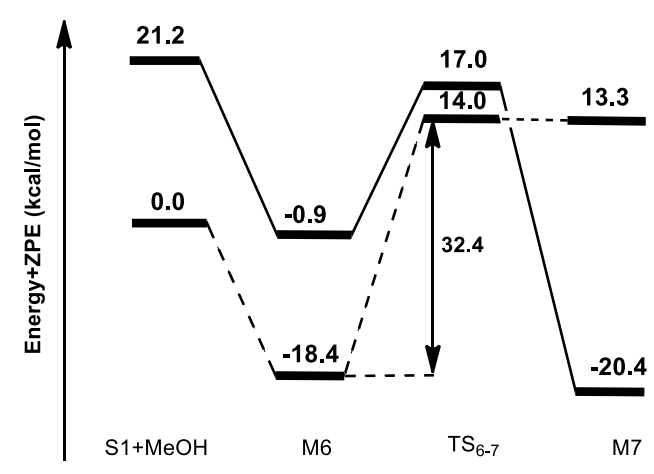

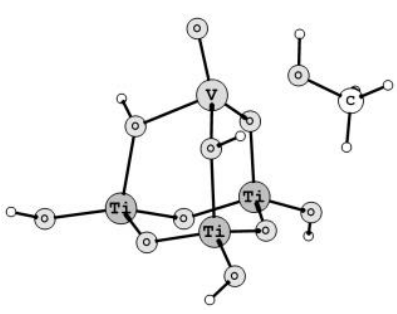

M6

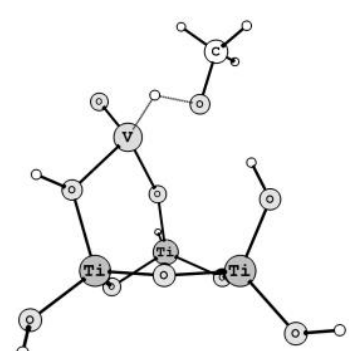

$\mathrm{TS}_{6-7}$

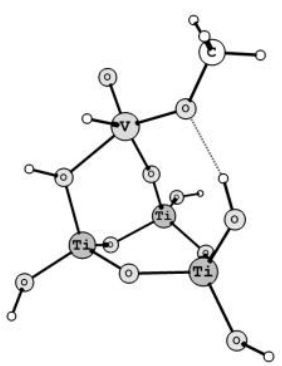

M7

Figure 6. Relevant geometries obtained at B3LYP/6-311G(2d,p) level and energy profile for the $\mathrm{CH}_{3} \mathrm{OH}$ adsorption process on vanadium site. 
Table 1. Selected properties to compare $\mathrm{V}(\mathrm{V}) / \mathrm{V}(\mathrm{III})$ catalysts for the oxidation reaction of $\mathrm{CH}_{3} \mathrm{OH}$. Energies in $\mathrm{kcal} / \mathrm{mol}$. surface. TS: transition state

\begin{tabular}{|c|c|c|c|}
\hline $\begin{array}{c}\text { Oxidation State } \\
\text { on Vanadium } \\
\text { Atom }\end{array}$ & $(\mathrm{III})^{\mathrm{a}}$ & $(\mathrm{V})^{\mathrm{b}}$ & Comparison \\
\hline Initial & $\begin{array}{l}\mathrm{V}^{(\mathrm{III})} \mathrm{O}_{4} \mathrm{H}_{2} \mathrm{Ti}_{3} \mathrm{O}_{\mathrm{x}} \text { (triplet) }+ \\
\mathrm{CH}_{3} \mathrm{OH}\end{array}$ & $\begin{array}{c}\mathrm{V}^{(\mathrm{V})} \mathrm{O}_{4} \mathrm{Ti}_{3} \mathrm{O}_{\mathrm{x}}(\text { singlet }) \\
\mathrm{CH}_{3} \mathrm{OH}\end{array}$ & - \\
\hline Final & $\begin{array}{l}\mathrm{V}^{(\mathrm{III})} \mathrm{O}_{4} \mathrm{H}_{2} \mathrm{Ti}_{3} \mathrm{O}_{x} \text { (triplet), } \mathrm{H}_{2} \\
+\mathrm{CH}_{2} \mathrm{O}\end{array}$ & $\begin{array}{c}\mathrm{V}^{(\mathrm{III})} \mathrm{O}_{4} \mathrm{H}_{2} \mathrm{Ti}_{3} \mathrm{O}_{\mathrm{x}} \text { (triplet) } \\
\mathrm{CH}_{2} \mathrm{O}\end{array}$ & - \\
\hline${ }^{\mathrm{c}} \Delta E_{\text {molec }}$ & $\begin{array}{c}\text { Exothermic } \\
(16-19 \mathrm{kcal} / \mathrm{mol})\end{array}$ & $\begin{array}{l}\text { Exothermic } \\
(7.0 \mathrm{kcal} / \mathrm{mol})\end{array}$ & $\begin{array}{l}\text { Molecular better } \\
\text { on } \mathrm{V}^{(I I I)}\end{array}$ \\
\hline$\Delta E_{\text {ads }}$ & $\begin{array}{c}\text { Exothermic } \\
(15.2-32.5 \mathrm{kcal} / \mathrm{mol})\end{array}$ & $\begin{array}{c}\text { Exothermic } \\
(17.1 \mathrm{kcal} / \mathrm{mol})\end{array}$ & $\begin{array}{c}\text { Better on } \mathrm{V}^{(\mathrm{III})} \text { than } \\
\mathrm{V}^{(\mathrm{V})}\end{array}$ \\
\hline $\begin{array}{c}\text { Methanol } \\
\text { adsorption site }\end{array}$ & $\mathrm{V}=\mathrm{O}$ and $\mathrm{V}-\mathrm{O}-\mathrm{Ti}$ & $\mathrm{V}-\mathrm{O}-\mathrm{Ti}$ & \\
\hline $\begin{array}{c}\text { Methanol } \\
\text { dissociation barrier }\end{array}$ & $6.9-13.2 \mathrm{kcal} / \mathrm{mol}$ & $10.7 \mathrm{kcal} / \mathrm{mol}$ & \\
\hline $\begin{array}{c}\text { Methoxy- } \\
\text { intermediate }\end{array}$ & $\begin{array}{c}\text { Pentahedral methoxide, } \\
\text { no } \mathrm{V}=\mathrm{O} \text { bond }\end{array}$ & $\begin{array}{c}\text { Tetrahedral methoxide } \\
\text { preferred, } \\
\mathrm{V}=\mathrm{O} \text { bond present }\end{array}$ & $\begin{array}{c}\text { Pentahedral } \\
\text { stabilized on } \mathrm{V}^{(\mathrm{III})} \\
\mathrm{V}=\mathrm{O} \text { only stable on } \\
\mathrm{V}^{(\mathrm{V})}\end{array}$ \\
\hline $\mathrm{C}-\mathrm{H}$ activation & By OH groups & By $\mathrm{V}=\mathrm{O}$ bonds & $\begin{array}{l}\text { In both cases this } \\
\text { is the rate-limiting } \\
\text { step }\end{array}$ \\
\hline${ }^{\mathrm{d}} \Delta E_{r l s}^{\dagger}$ & $\begin{array}{c}36.4,53.5 \text { and } 29.0 \\
\mathrm{kcal} / \mathrm{mol}\end{array}$ & $41.0 \mathrm{kcal} / \mathrm{mol}$ & - \\
\hline $\mathrm{TS}_{\mathrm{rls}} / \mathrm{OSV}^{\mathrm{e}}$ & Triplet; $\mathrm{V}^{3+}$ & Biracaloid $(\mathrm{OSS})^{\mathrm{e}} ; \mathrm{V}^{(\mathrm{IV})}$ & - \\
\hline Electron transfer & $\begin{array}{c}\text { Two electrons: directly } \\
\text { from methoxide group to } \\
\mathrm{H}_{2}\end{array}$ & $\begin{array}{c}\text { Two electrons: from } \\
\text { methoxide the catalyst } \\
\mathrm{V}^{(\mathrm{V})} \text {, as a consequence } \\
\mathrm{V}^{(\mathrm{V})} \rightarrow \mathrm{V}^{(\mathrm{III})}\end{array}$ & - \\
\hline Spin crossing? & $\begin{array}{c}\text { No, only triplet ground } \\
\text { state }\end{array}$ & Yes, singlet $\rightarrow$ triplet & - \\
\hline $\begin{array}{l}\text { Formation of } \\
\text { hydride } \\
\text { intermediate? }\end{array}$ & $\begin{array}{c}\text { Exothermic }(-20.4 \\
\mathrm{kcal} / \mathrm{mol}) \\
\text { Barrier: } 32.4 \mathrm{kcal} / \mathrm{mol} \\
\text { Triplet } \rightarrow \text { singlet }\end{array}$ & - & - \\
\hline
\end{tabular}

${ }^{a}$ This paper. ${ }^{b}$ Ref $70 .{ }^{c}$ Molecular adsorption of methanol on surface. ${ }^{d}$ Activation energy for rate-limiting step ${ }^{\circ}$ Open Shell Singlet. 